\title{
DETECTION OF MYCOBACTERIUM AVIUM SUBSPECIES PARATUBERCULOSIS IN RAW BULK TANK MILK
}

\author{
ABDEL MOGHNEY, A.F. ${ }^{1}$ and NASHWA, M. HELMY ${ }^{2}$ \\ ${ }^{1}$ Bacteriology Department, Provincial Labs, Animal Health Research Institute, Dokki, Giza, Egypt \\ ${ }^{2}$ Biotechnology Department, Animal Health Research Institute, Dokki, Giza, Egypt
}

Received: 28 March 2017; $\quad$ Accepted: 30 April 2017

\begin{abstract}
In this study, twenty five bulk tank milk samples each of 50ml from Bulk tank milk of 25 holstein-friesian dairy herds representing 7 Egyptian Governorates, were collected at the period from January to July 2013. Each raw bulk tank milk sample was subjected to ELISA and real time PCR, while detection of viable Mycobacterium avium subsp. paratuberculosis (MAP) was done by culture of milk samples on Herrold's egg yolk media "HEYM". The results indicated that real time PCR detected 17out of 25 samples $(68 \%)$ followed by ELISA 10 samples out of 25 (40\%), more over the viable MAP was isolated from 15 out of 25 samples (60\%), the autors indicated the high percentage of MAP isolation may be to milk contamination with infected faeces and shedded microorganisms directly in milk. The authors concluded that, Since the milk is considered an essential nutrient for childrens and adults, it should be free of any hazard pathogens could be transmitted to it by direct or indirect way, so it is very important in milk value chain to test the raw bulk milk provided to plant milk processing by efficient and fast test as real time PCR to exclude any possible threat for the consumer by using the efficient pasteurization for that pathogen.
\end{abstract}

Key words: Mycobacterium Avium, Paratuberculosis, Raw, Milk.

\section{INTRODUCTION}

MAP is the causative agent of ruminant paratuberculosis (Johne's disease), which has become a worldwide problem. Clinically infected cows can shed from $<100 \mathrm{cfu} / \mathrm{ml}$ to as high as $1000 \mathrm{cfu} / \mathrm{ml}$ of milk, while subclinically infected animals can also shed an average of $4 \times 10^{2} \mathrm{cfu} / \mathrm{ml}$ to $16 \times 10^{2} \mathrm{cfu} / \mathrm{ml}$ of milk. Milk may be contaminated with MAP by two routes: organisms directly shed into the milk via the udder, or secondly, by contaminated faecal material. (Sweeney et al., 1992; Giese and Ahrens, 2000). MAP infection of domestic-food-producing animals is associated with significant economic loss to the livestock industry worldwide. At present, preventive strategies to restrict the spread of MAP in animal populations and to limit the economic loss are not satisfactory. This is because of the relatively low sensitivities of the currently available tests, which failto detect many subclinically MAP-infected animals (Logar et al., 2012). The subclinical infection are found in a majority of animals with no clinical signs.

Corresponding author: Dr. ABDEL MOGHNEY, A.F.

E-mail address: abdelrasheedghanem28@gmail.com

Present address: Bacteriology Department, Provincial Labs, Animal Health Research Institute, Dokki, Giza, Egypt
These animals (often highly productive) become sources of infection for other susceptible animals, shedding MAP into the external environment in their milk and faeces (Corti and Stephan, 2002).

MAP has long been suspected as a causative agent for Crohn's disease in humans, which exhibits a similar pathology to Johne's disease (Skovgaard, 2007; Behr and Kapur, 2008). The presence of MAP in milk and in dairy products could therefore pose a potential hazard to human health (Slana et al., 2008; Behr and Kapur, 2008).

MAP can find its way through to the human food chain because it can survive conventional pasteurization of milk at $71.7{ }^{\circ} \mathrm{C}$ for $15 \mathrm{~s}$ (Grant, 2006 and Slana et al., 2008).

The gold standard technique for MAP identification is still based on bacterial culture on solid media of faecaland milk samples. The slow growth (up to 16 weeks) and false negatives in samples that have low concentrations of MAP makes it difficult to implement efficient protective strategies in an animal population when the MaP identification is solely based on bacterial cultivation. Likewise, enzymelinked immunosorbent assays (ELISA) for the detection of antibodies against MAP in milk and serum lack sensitivity. Because of these reasons, a rapid, cost-effective, and automated diagnosis of this 
pathogen is a high priority task not only for animal breeders but also for the food production industry and for public health institutions. Quantitative real-time PCR (qPCR) is an alternative to bacterial culture and immunological methods, since it is a rapid test that can provide higher sensitivity (Logar et al., 2012).

Since consumption of milk and dairy products is considered one of the main routes of human exposure to Mycobacterium avium subsp. paratuberculosis (MAP), the aim of this study was using real time PCR and ELISA for detection of MAP and antibodies in raw bulk tank milk of some dairy herds as a fast useful tools for control the introduction of such pathogen into the human food chain.

\section{MATERIALS AND METHODS}

Twenty five bulk tank milk samples each of $50 \mathrm{ml}$ were collected aseptically from Bulk tank milk of 25 holstein-friesian dairy herds representing 7 Egyptian governorates, (Alexandria $n=6$, Behaira $n=5$, Gharbia $\mathrm{n}=7$, Menofia $\mathrm{n}=1$, Dakahlia $\mathrm{n}=3$, Sharkya $\mathrm{n}=1$ and Ismaelia $\mathrm{n}=2$ ), were examined for detection of Mycobacterium paratuberculosis, at the period from January to July 2013.

Milk samples were transferred in ice box to laboratory and kept at $-20{ }^{\circ} \mathrm{C}$ till test. Each raw bulk tank milk sample was subjected to ELISA and real time PCR, while detection of viable MAP was done by culture of milk samples on Herrold's egg yolk media "HEYM".

\section{1- Enzyme Linked Immunosorbent Assay (ELISA) according to OIe (2004):}

Detection of anti-MAP antibodies by ELISA in bovine bulk tank milk using a modified method of a commercial ELISA kit, manufactured by "institute pourquir, a subsidiary of IDEXX Laboratories, inc. France" and interpretation of results according to equation provided by the manufacturer kit.

\section{2-Real time PCR}

- DNA extraction from milk samples: 1400 ul of milk samples were transferred to 1.5 micro centrifuge tubes and centrifuged at $3000 \mathrm{rpm}$ for 5 min. After centrifugation, cream and whey layers were discarded and pellet were transferred into new micro tubes. DNA were extracted using the Abbott m Sample preparation system DNA kit (Promega) according to the manufacture. Finally extracted DNA stored at $-20{ }^{\circ} \mathrm{C}$ till used in Real-time PCR

- Real-time PCR probe and primers: a set of primer and probe were used to amplify an 84-bp fragment of IS900 from MAP (Table 1) (Khare et al., 2004).

Oligonucleotide sequences of primers and probe used in this study specific for MAP

\begin{tabular}{cc}
\hline & Sequences \\
\hline Forward & CGG GCG GCC AAT CTC \\
\hline Reverse & CCA GGG ACG TCG GGT ATG \\
\hline Probe & FAM TTC GGC CAT CCA ACA CAG CAA CC TAMRA \\
\hline
\end{tabular}

- DNA amplification in real time PCR: Quantitative real time PCR was performed on each sample using qPCR Probes Master mix with ROX (Jena bioscience Cat. No. PCR-312S) Reaction mixture was composed of $2 \mathrm{ul}$ of DNA template and $10 \mathrm{ul}$ of a master mix in a tube,10 PM of each primer, 5 PM of probe and DNA and RNA free sterile distilled water till reach $20 \mathrm{ul}$. The optimized cycle program of denaturation, annealing and extension temperature was as follows: 1 cycle $50{ }^{\circ} \mathrm{C}$ for 2 min. for UNG (Uracil-N-Glycosylase) treatment: initial denaturation at $95{ }^{\circ} \mathrm{C}$ for $2 \mathrm{~min}$; then 50 cycles consisting of $95{ }^{\circ} \mathrm{C}$ for $10 \mathrm{~s}$ and $60{ }^{\circ} \mathrm{C}$ for 1 min. (Khare et al., 2004). Negative control specimen was involved. Real time PCR were conducted on one step Applied Biosystem.
3-Isolation of MAP from bulk tank milk by bacteriological culture methods:

Culture of bulk tank milk samples on Herrolds's egg yolk medium (HEYM) supplemented with mycobactin $\mathbf{J}$ as a gold standard method for confirmation of presence of viable MAP were done according to (Sweeney et al., 1992).

\section{RESULTS}

Results are presented in Table (1) demonstrate the association between the results of different tests (ELISA, real time PCR and culture). There was agreement between ELISA and PCR in 10 of the 25 milk samples (40\%) and between culture and PCR in 15 out of 25 milk samples included in the analysis. 
The CT values of positive samples with real time PCR ranged between 14 and 34 as shown in Fig. 1.

Seven samples were positive for PCR but negative for ELISA however two samples were PCR positive but negative for culture. The data suggest that ELISA sero-reactivity may have a negative status despite the fact that the cow is shedding the bacteria in milk, as shown by PCR detection.

Table1: Results of ELISA, real time PCR and culture, of bulk tank milk for detection of MAP.

\begin{tabular}{ccccc}
\hline Governorate & No. & ELISA+ve & PCR+ve & Culture+ve \\
\hline Alexandria & 6 & 1 & 4 & 4 \\
\hline Behaira & 5 & 1 & 2 & 3 \\
\hline Gharbia & 7 & 3 & 5 & 1 \\
\hline Menofia & 1 & 1 & 2 & 1 \\
\hline Dakahlia & 3 & 2 & 1 & 2 \\
\hline Sharkia & 1 & 1 & 2 & $15 / 25(60 \%)$ \\
\hline Ismaelia & 2 & 1 & $17 / 25(68 \%)$ & 2 \\
\hline Total $(\%)$ & 25 & $10 / 25(40 \%)$ & & 2 \\
\hline+ ve=positive & & & & 2 \\
\hline
\end{tabular}

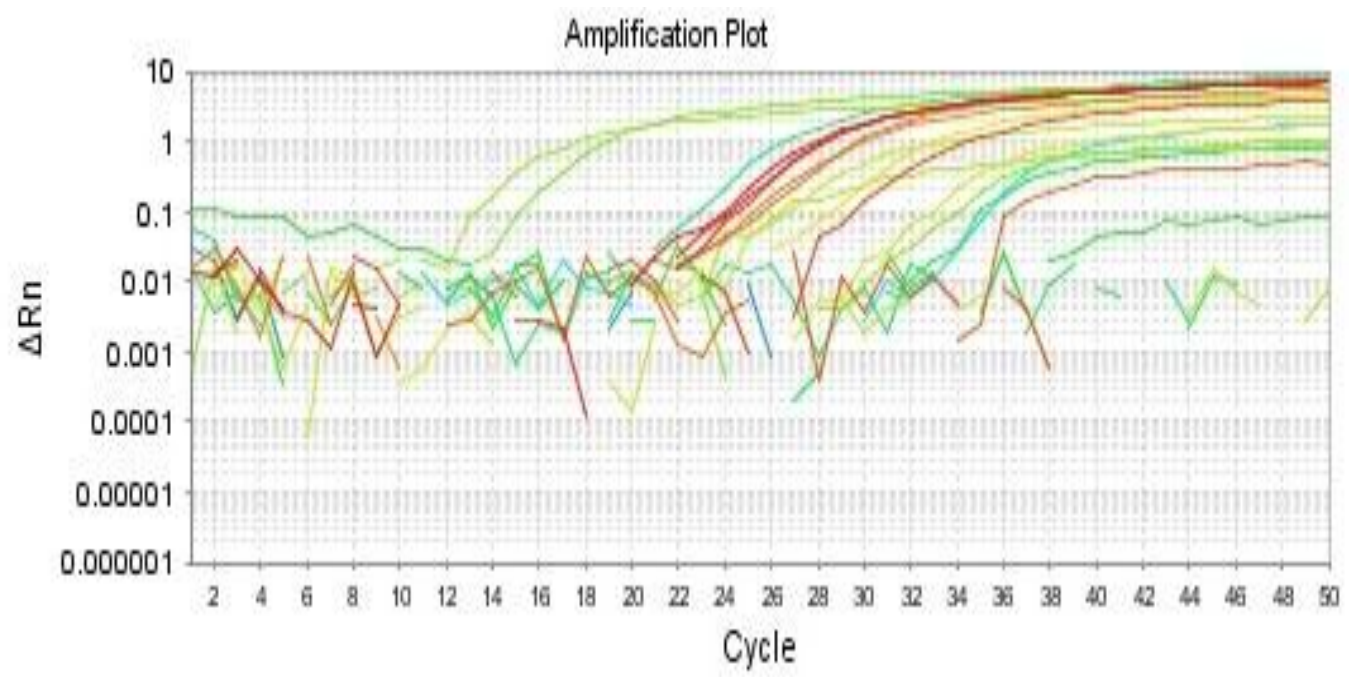

Fig. (1): Amplification plot of real time PCR applicated on 25 milk samples by using primers and Taq Man probe specific for IS900 gene from MAP.

\section{DISCUSSION}

Paratuberculosis in ruminants is being increasingly recognized as a major herd health problem; thus, there is a need for a reliable diagnostic tool for largescale use to facilitate control programs, reduce risk hazard of contaminated milk and eventually eradicate the disease. The utilization of bulk milk sample testing is a practical way to screen dairy herds for presence of Johne's disease "JD". As shown in table (1) ELISA test detected antibodies for MAP in 10 out of 25 bulk milk samples which in comparison with culture "gold standard " and PCR will be the highest test for MAP detection beside its speed and low cost (Gilardoni et al., 2012). It is often the method of choice for epidemiological studies and fast additional tool for MAP diagnosis (Böttcher and Gangl 2004).

Several PCR based on IS900 have been developed for the detection of MAP. Unfortunately, the actual performance of these techniques is limited by various factors that include isolation of organism- specific DNA and PCR amplification in the presence of inhibitory substances in preferred clinical specimens. 
Milk is considered to be a difficult specimen for the detection of organisms by PCR, due to the presence of large amounts of fat and calcium ions (Lantez et al., 1994). In the present study, $17(68 \%)$ out of the 25 bulk tank milk samples were IS900 PCR- positive. The detection of IS 900 by PCR provide presumptive evidence of the presence of MAP. The prevalence of (68\%) IS900 PCR-positive bulk-milk samples shows a wide distribution of subclinical MAP infections in dairy stocks. Since not all animals which are subclinically infected with MAP shed the organism in the milk and moreover this excretion is intermittent, it is probable that there are stocks with sub-clinically infected animals which have not at the time of sample collection shed MAP in the milk (Corti \& Stephan, 2002). It is therefore possible that the prevalence of sub- clinically infected dairy stocks is even higher than we have found.

Seven samples were positive by PCR but negative by ELISA table (1), this regarded to the ELISA test which targets antibodies in the bulk tank, coming only from infected cow milk and are the result of a variable and delayed humoral response to MAP infection (Stabel, 2006), In addition of the positive correlation between MAP herd prevalence and vice versa which play an essential role in milk's MAP antibody dilution.

On the other hand, the real time PCR targets the presence of MAP DNA, which can come from milk or environmental contamination and is generally shed in manure earlier during the progression of paratuberculosis. Consequently, agreement between the 2 tests would be affected by factors other than test performance, including disease prevalence within herd, proportion of infected animals in later stages of disease, and milking hygiene (Sweeney et al., 2006).

Out of 25 bulk milk samples 15 (60\%) were positive by culture, two samples were negative by culture and positive by real time PCR which agree with Botsaris et al. (2010) who mentioned that, Real time PCR is more sensitive than the conventional culture when testing raw milk samples for MAP may be shed into milk or transferred to milk by faecalcontamination, it will probably occur in low numbers in the bulk tank milk due to dilution as well as general milking hygiene measures. The concentration of MAP can therefore be assumed to often fall below the detection limit of culture method. Culture

In the present study results of ELISA, PCR and culture were in disagreement with results of Logar et al. (2012) that recorded, $1 \%, 36 \%$ and $19 \%$ for ELISA, PCR and culture respectively thus, PCR detection of MAP in milk would be more useful for control of MAP presence in milk, in order to avoid transfer to humans, than for herd prevalence testing
(Herthnek et al., 2008), moreover real time PCR minimizes the risk of false positive results due to amplicon contamination due to the use of probes which enhances the specificity of the reaction (Herthnek and Bölske, 2006).

\section{CONCLUSION}

Since the milk is considered an essential nutrient for children and audult, it should be free of any hazard pathogens that could be transmitted to it by direct or indirect way. So it is very important in milk value chain to test the raw bulk milk provided to plant milk processing by efficient and fast test as real time PCR to exclude any possible threat for the consumer by using the efficient pasteurization for that pathogen.

\section{REFERENCES}

Behr, M.A. and Kapur, V. (2008): The evidence for Mycobacterium paratuberculosis in Crohn's disease. Current Opinion in Gastroenterology 24, 17-21.

Botsaris, G.; Slana, I.; Liapi, M.; Dodd, C.; Economides, C.; Rees, C. and Pavlik, I. (2010): Rapid detection methods for viable Mycobacterium avium subspecies paratuberculosis in milk and cheese. Int. J. Food Microbiol. 31;141Suppl 1:S87-90 [Pubmed].

Böttcher, J. and Gangl, A. (2004): Mycobacterium avium ssp. paratuberculosis-combined serological testing and classification of individual animals and herds. J .Veterinarandy Med Ser B.; 51(10):443-8.

Corti, S. and Stephan, R. (2002): Detection of Mycobacterium avium subspecies paratuberculosis specific IS900 insertion sequences in bulk-tank milk samples obtained from different regions throughout Switzerland. BMC Microbiology, 2, 15. http://doi. org/10. 1186/1471-2180-2-15.

Giese, SB. and Ahrens, P. (2000): Detection of Mycobacterium avium subsp. paratuberculosis in milk from clinically affected cows by PCR and culture. Vet. Microbiol 77:291-297.

Gilardoni, LR.; Paolicchi, FA. And Mundo SL. Bovine (2012): Paratuberculosis: a review of the advantages and disadvantages of different diagnostic tests. Rev Argent Microbiol. 2012; 44: 201-15.

Grant, I.R. (2006): $\quad$ Mycobacterium aviumsspparatuberculosis in foods: current evidence and potential consequences. International Journal of Dairy Technology 59, 112-117.

Herthnek, D.; Nielsen, S.S.; Lindberg, A. and Bölske, G. (2008): A robust method for bacterial lysis and DNA purification to be used with realtime PCR for detection of Mycobacterium 
avium subsp. Paratuberculosis in milk. J. Microbiol. Methods. Oct;75(2): 335-40.

Logar, K.; Kopinč, R.; Bandelj, P.; Starič, J.; Lapanje, A. and Ocepek, M. (2012): Evaluation of combined high-efficiency DNA extraction and real-time PCR for detection of Mycobacterium avium subsp. paratuberculosis in subclinically infected dairy cattle: comparison with faecal culture, milk real-time PCR and milk ELISA. BMC Veterinary Research, 8(1), 49. http://doi.org/10.1186/ 1746-6148-8-49.

Office International Des Epizooties "Oie" (2004): Manual of Diagnostic Tests and Vaccines for Terrestrial Animals. Paratuberculosis. Chapter 2.2.6

Skovgaard (2007): New trends in emerging pathogens. International Journalof Food Microbiology 120, 217-227.
Slana, I.; Paolicchi, F.; Janstova, B.; Navratilova, P. and Pavlik, I. (2008): Detection methods for Mycobacterium avium subsp paratuberculosis in milk and milk products: a review. Veterinarni Medicina-Praha-, 53(6), 283-306.

Stabel, J.R. (2006): Host responses to Mycobacterium avium ssp. paratuberculosis: A complex arsenal. Anim. Health Res. Rev. 7:61-70.

Sweeney, R.; Whitlock, R.H. and Rosenberger, A.E. (1992): Mycobacterium paratuberculosis cultured from milk and supramammary lymph nodes of infected asymptomatic cows. J. Clin. Microbiol. 30:166-171.

Sweeney, R.W.; Whitlock, R.H.; McAdams, S. and Fyock, T. (2006): Longitudinal study of ELISA seroreactivity to Mycobacterium avium ssp. paratuberculosis in infected cattle and culture-negative herd mates. J. Vet. Diagn. Invest. 18:2-6.

\section{الكثف عن ميكوياكتريم نظير السل في خزان اللبن الخام

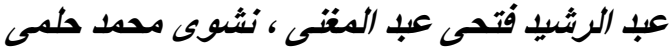

Email: abdelrasheedghanem28@gmail.com Assiut University web-site: www.aun.edu.eg

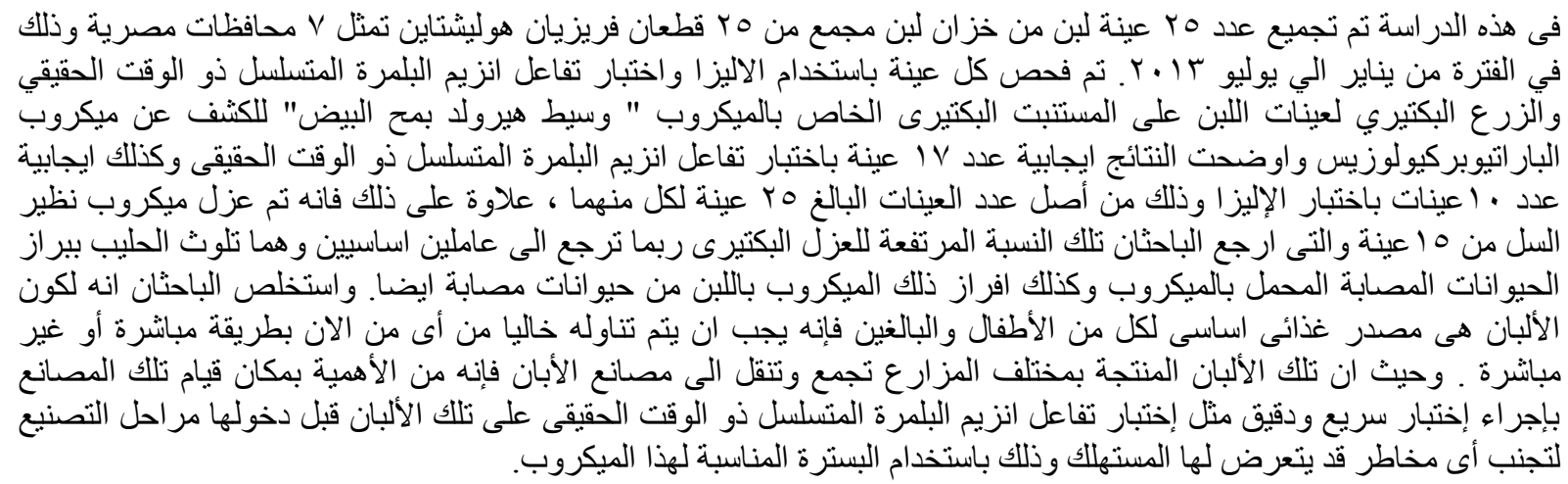

